\title{
AKT1 wt Allele
}

National Cancer Institute

\section{Source}

National Cancer Institute. AKT1 wt Allele. NCI Thesaurus. Code C51182.

Human AKT 1 wild-type allele is located in the vicinity of $14 q 32.32$ and is approximately 26 $\mathrm{kb}$ in length. This allele, which encodes RAC-alpha serine/threonine-protein kinase protein, plays a role in mediating the effects of various growth factors and is involved in the transduction of anti-apoptotic and proliferation signals in T-cells. Inherited defects in the AKT 1 gene that result in deficiency of its protein product confer susceptibility to schizophrenia. 